\title{
APPLICATION OF LEARNING THE KOOPERATIF TIPE TALKING STICK DALAM BELAJAR AL-QUR'AN SISWA MADRASAH IBTIDAIYYAH (MI)
}

\author{
Oleh: \\ Asnawan \\ (Dosen PAI INAIFAS Kencong Jember) \\ asnawanwan@gmail.com
}

\begin{abstract}
Cooperative learning is a form of learning by the way students learn and work in small groups collaboratively whose members consist of four to six people with heterogeneous group structures. The talking stick is one type of simple cooperative learning. The teacher divides the class into groups with five or six heterogeneous members. Groups are formed by considering different friendships, intelligence, friendships, or interests. Groups that hold sticks must first answer questions from the teacher after they learn the subject matter. This activity is repeated continuously until all groups have a turn to answer questions from the teacher.
\end{abstract}

Keywords: Application Of Learning The Kooperatif Tipe Talking Stick, Belajar Al-Qur'an

\begin{abstract}
ABSTRAK
Pembelajaran kooperatif merupakan bentuk pembelajaran dengan cara siswa belajar dan bekerja dalam kelompok-kelompok kecil secara kolaboratif yang anggotanya terdiri dari empat sampai enam orang dengan struktur kelompok yang bersifat heterogen. Talking stick (tongkat berbicara) adalah salah satu tipe pembelajaran kooperatif yang sederhana. Guru membagi kelas menjadi kelompok-kelompok dengan anggota lima atau enam siswa yang heterogen. Kelompok dibentuk dengan mempertimbangkan keakraban, kecerdasan, persahabatan, atau minat yang berbeda. Kelompok yang memegang tongkat terlebih dahulu wajib menjawab pertanyaan dari guru setelah mereka mempelajari materi pokoknya. Kegiatan ini diulang terusmenerus sampai semua kelompok mendapat giliran untuk menjawab pertanyaan dari guru.
\end{abstract}

Kata Kunci: Application Of Learning The Kooperatif Tipe Talking Stick, Belajar Al-Qur'an

\section{PENDAHULUAN}

Perkembangan ilmu pengetahuan dan teknologi telah membawa perubahan yang sangat signifikan terhadap berbagai jenis dimensi kehidupan manusia, baik dalam ekonomi, sosial, budaya, maupun pendidikan. Dalam UU. No. 20 tahun 2003 tentang sistem pendidikan Nasional bab I pasal I menyebutkan bahwa:

Pendidikan adalah usaha sadar dan terencana untuk mewujudkan suasana belajar dan proses pembelajaran agar peserta didik secara aktif mengembangkan potensi dirinya untuk memiliki kekuatan spiritual keagamaan, pengendalian diri, kepribadian, kecerdasan, 
akhlak mulia, serta keterampilan yang diperlukan dirinya, masyarakat, bangsa, dan negara. ${ }^{1}$

Pendidikan adalah segala pengalaman belajar yang berlangsung dalam segala lingkungan dan sepanjang hidup. Sedangkan pengertian belajar adalah perubahan disposisi atau kemampuan yang dicapai seseorang melalui aktivitas. ${ }^{2}$ Perubahan disposisi tersebut bukan diperoleh langsung dari proses pertumbuhan seseorang secara alamiah. Belajar pada hakikatnya adalah proses interaksi terhadap semua situasi yang ada di sekitar individu.

Dalam konteks sekolah, seorang anak dikatakan telah belajar manakala perubahanperubahan yang terjadi pada anak sesuai dengan kebutuhan- kebutuhan sekolah dan masyarakat. Jadi, terhadap hal yang bersifat negatif dan tidak sesuai dengan kebutuhan sekolah dan masyarakat, maka tidak dapat dikatakan belajar walaupun diperoleh melalui latihan atau pengalaman. ${ }^{3}$ Bersamaan dengan berkembangnya pendidikan di sekolah umum, perhatian terhadap madrasah atau pendidikan Islam sangat kurang, dulu pengajarannya dilaksanakan di surau, masjid, atau pondok pesantren. Dari segi pendidikan mulanya madrasah identik dengan belajar mengaji Al-Qur'an, jenjang pengajian kitab dasar dan tingkat lanjut. Madrasah merupakan salah satu lembaga sekolah yang didalamnya termuat kurikulum dalam bidang agama Islam. Mata pelajaran Al-Qur'an Hadits adalah salah satu mata pelajaran yang diajarkan di Madrasah Ibtidaiyah. Daradjat mengatakan bahwa:

Mata pelajaran Al-Qur an Hadits merupakan perencanaan dan pelaksanaan program pengajaran membaca dan mengartikan atau menafsirkan ayat-ayat Al-Qur'an dan hadits-hadits tertentu, yang sesuai dengan kepentingan siswa menurut tingkat-tingkat madrasah yang bersangkutan, sehingga dapat dijadikan modal kemampuan untuk mempelajari, meresapi dan menghayati pokok-pokok Al-Qur'an dan Al-Hadits dan menarik hikmah yang terkandung di dalam secara keseluruhan. ${ }^{4}$

Ruang lingkup pengajaran Al-Qur'an Hadits di MI meliputi: ${ }^{5}$

1. Pengetahuan dasar membaca dan menulis Al-Qurean.

2. Hafalan surat-surat pendek.

3. Pemahaman kandungan surat-surat pendek.

4. Hadits-hadits tentang kebersihan, niat, menghormati orang tua, persaudaraan, silaturrahim, taqwa, menyayangi anak yatim, shalat berjamaah, ciri-ciri orang munafik, dan beramal shaleh.

${ }^{1}$ Undang-Undang RI No. 20 Tabun 2003 tentang Sistem Pendidikan Nasional, (Jakarta: Sinar Grafida, 2009), hal. 3

2 Agus Suprijono, Cooperative Learning: Teori dan Aplikasi PAIKEM, (Yogyakarta: Pustaka Pelajar, 2009), hal. 2

3 Annisatul Mufarrokah, Strategi Belajar Mengajar, (Yogyakarta: Teras, 2009), hal. 134 Zakiah Daradjat, dkk., Metodik Khusus Pengajaran Agama Islam, Jakarta: Bumi Aksara,

${ }^{4}$ Zakiah Daradjat, dkk., Metodik. Khusus Pengajaran Agama Islam, (Jakarta: Bumi Aksara, 2008), hal. 172

${ }^{5}$ Lily Azkiya, "Pelajaran Al-Qur'an Hadits" dalam, diakses 15 Februari 2018

Vol.DI. No.DZ. April 2019 
Mata pelajaran Al-Quran Hadits dirasakan sebagai mata pelajaran yang kurang diperhatikan oleh siswa karena dianggap kurang menarik sebab pembahasannya yang terlalu monoton. Mata pelajaran Al-Qur'an Hadits yang diajarkan di MI merupakan suatu mata pelajaran yang berisikan tentang surat-surat pendek, tajwid, dan hikmah atau isi kandungan yang terdapat dalam surat-surat pendek. Siswa yang latar belakangnya dari keluarga yang beragama kuat dan belajar mengaji di lingkungan rumahnya akan bisa mengikuti pelajaran ini tanpa beban, karena siswa juga dituntut untuk menghafalkan surat-surat pendek beserta artinya. Bagi siswa yang latar belakangnya tidak didukung oleh keluarga yang beragama kuat atau belajar mengaji di lingkungan rumahnya pasti merasa jenuh dan banyak keluhan, sehingga mata pelajaran ini kurang menarik apabila tidak ada cara penyampaian yang inovatif dan bervariasi.

\section{PEMBAHASAN}

\section{A. Hakekat Pembelajaran Kooperatif}

\section{Pengertian Pembelajaran Kooperatif}

Pembelajaran adalah sesuatu yang dilakukan oleh siswa, bukan dibuat untuk siswa. Pembelajaran pada dasarnya merupakan upaya pendidik untuk membantu peserta didik melakukan kegiatan belajar. Tujuan pembelajaran adalah terwujudnya efisiensi dan efektivitas kegiatan belajar yang dilakukan peserta didik. Pembelajaran kooperatif adalah salah satu bentuk pembelajaran yang berdasarkan faham konstruktivis. ${ }^{6}$ Dalam pembelajaran kooperatif diterapkan strategi belajar dengan sejumlah siswa sebagai anggota kelompok kecil yang tingkat kemampuannya berbeda. Dalam menyelesaikan tugas kelompoknya, setiap anggota kelompok harus saling bekerja sama dan saling membantu untuk memahami materi pelajaran. Dalam pembelajaran ini, belajar dikatakan belum selesai jika salah satu teman dalam kelompok belum menguasai bahan pelajaran. Slavin mengemukakan bahwa:

Cooperative learning adalah suatu model pembelajaran dimana siswa belajar dan bekerja dalam kelompok-kelompok kecil secara kolaboratif yang anggotanya empat sampai enam orang dengan struktur kelompok heterogen. ${ }^{7}$

Maksud kelompok heterogen adalah terdiri atas campuran kemampuan siswa, jenis kelamin, dan suku. Dengan demikian, pembelajaran kooperatif bergantung pada efektivitas kelompok-kelompok siswa tersebut. Masing-masing anggota kelompok bertanggung jawab

\footnotetext{
${ }^{6}$ Isjoni, Cooperative Learning: Mengembangkan Kemampuan Belajar Berkelompok, (Bandung: Alfabeta, 2011), hal. 11

${ }^{7}$ Nur Asma, Model Pembelajaran Kooperatif, (Jakarta: Departemen Pendidikan Nasional , 2006), hal. 11 
mempelajari apa yang disajikan dan membantu teman-teman satu anggota untuk mempelajarinya juga.

\section{Karakteristik Pembelajaran Kooperatif}

Pembelajaran kooperatif berbeda dengan strategi pembelajaran yang lain. Perbedaan tersebut dapat dilihat dari proses pembelajaran yang lebih menekankan pada proses kerja sama dalam kelompok. Tujuan yang ingin dicapai tidak hanya kemampuan akademik dalam pengertian penguasaan materi pelajaran, tetapi juga adanya unsur kerja sama untuk penguasaan materi tersebut. Adanya kerja sama inilah yang menjadi ciri khas dari pembelajaran kooperatif. Karakteristik pembelajaran kooperatif dapat dijelaskan sebagai berikut: ${ }^{8}$

a. Pembelajaran Secara Tim

Pembelajaran kooperatif adalah pembelajaran dilakukan secara tim. Tim merupakan tempat untuk mencapai tujuan. Oleh karena itu, tim harus mampu membuat setiap siswa belajar. Setiap anggota tim harus saling membantu untuk mencapai tujuan pembelajaran.

b. Didasarkan pada Manajemen Kooperatif

Manajemen mempunyai empat fungsi pokok, yaitu:

1) Fungsi perencanaan

Menunjukkan bahwa pembelajaran kooperatif memerlukan perencanaan yang matang agar proses pembelajaran berjalan secara efektif.

2) Fungsi pelaksanaan

Menunjukkan bahwa pembelajaran kooperatif harus dilaksanakan sesuai dengan perencanaan, melalui langkah-langkah pembelajaran yang sudah ditentukan termasuk ketentuan-ketentuan yang sudah disepakati bersama.

3) Fungsi organisasi Menunjukkan bahwa pembelajaran kooperatif adalah pekerjaan bersama antar setiap anggota kelompok, oleh sebab itu perlu diatur tugas dan tanggung jawab setiap anggota kelompok.

4) Fungsi kontrol Menunjukkan bahwa dalam pembelajaran kooperatif perlu ditentukan kriteria keberhasilan baik melalui tes maupun non tes.

c. Kemauan untuk Bekerja Sama

\footnotetext{
${ }^{8}$ Rusman, Model-model Pembelajaran: Mengembangkan Profesionalisme Guru, (Jakarta: PT. Raja Grafindo Persada, 2012), hal. 207-208

Vol.DI. No.DZ. April 2019

Jurnal Auladuna | 81
} 
Keberhasilan pembelajaran kooperatif ditentukan oleh keberhasilan secara kelompok, oleh karenanya prinsip kebersamaan atau kerja sama perlu ditekankan dalam pembelajaran kooperatif. Tanpa kerja sama yang baik, pembelajaran kooperatif tidak akan mencapai hasil yang optimal.

d. Keterampilan Bekerja Sama

Kemampuan bekerja sama itu dipraktikkan melalui aktivitas dalam kegiatan pembelajaran secara berkelompok. Dengan demikian, siswa perlu didorong untuk mau dan sanggup berinteraksi dan berkomunikasi dengan anggota lain dalam rangka mencapai tujuan pembelajaran yang telah ditetapkan.

\section{Unsur-unsur Pembelajaran Kooperatif}

Ada lima unsur model pembelajaran kooperatif yang harus diterapkan untuk mencapai hasil yang maksimal, yaitu:'

a. Saling Ketergantungan Positif

Ketergantungan yang positif adalah suatu bentuk kerja sama yang sangat erat kaitan antara anggota kelompok. Kerja sama ini dibutuhkan untuk mencapai tujuan. Siswa benar-benar mengerti bahwa kesuksesan kelompok tergantung pada kesuksesan anggotanya. Kegagalan dan keberhasilan kelompok merupakan tanggung jawab setiap anggota kelompok. Oleh karena itu, sesama anggota kelompok harus merasa terikat dan saling tergantung positif.

b. Tanggung Jawab Perseorangan

Tanggung jawab perseorangan adalah kelompok tergantung pada cara belajar perseorangan seluruh anggota kelompok. ${ }^{10}$ Pertanggung jawaban memfokuskan aktivitas kelompok dalam menjelaskan konsep pada satu orang dan memastikan bahwa setiap orang dalam kelompok siap menghadapi aktivitas lain dimana siswa harus menerima tanpa pertolongan anggota kelompok. Setiap anggota kelompok bertanggung jawab untuk menguasai materi pelajaran karena keberhasilan belajar kelompok ditentukan dari seberapa besar sumbangan hasil belajar secara perorangan.

c. Tatap Muka

\footnotetext{
9 Anita Lie, Cooperative Learning: Mempraktikkan Cooperative Learning di Ruang-ruang Kelas, (Jakarta: Gramedia, 2007), hal. 29-33

${ }^{10}$ Rusman, Model-model Pembelajaran: Mengembangkan .., hal. 204

82 | Jurnal Auladuna

Vol.DI. No.Q2. April 2019
} 
Dalam pembelajaran kooperatif setiap kelompok diberikan kesempatan untuk bertatap muka dan berdiskusi. Kegiatan interaksi ini akan memberi siswa bentuk sinergi yang menguntungkan semua anggota. Inti hubungan yang menguntungkan ini adalah menghargai perbedaan, memanfaatkan kelebihan, dan mengisi kekurangan masingmasing.

d. Komunikasi Antar Anggota

Unsur ini menghendaki agar para siswa dibekali dengan berbagai keterampilan berkomunikasi karena keberhasilan suatu kelompok juga bergantung pada kesediaan para anggotanya untuk saling mendengarkan dan kemampuan mereka untuk mengutarakan pendapat mereka. Keterampilan berkomunikasi dalam kelompok juga merupakan proses panjang. Namun, proses ini merupakan proses yang sangat bermanfaat dan perlu ditempuh untuk memperkaya pengalaman belajar dan pembinaan perkembangan mental dan emosional para siswa.

e. Evaluasi Proses Kelompok

Guru perlu menjadwalkan waktu khusus untuk mengevaluasi proses kerja kelompok dan hasil kerja sama mereka agar selanjutnya bisa bekerja sama dengan lebih efektif. Waktu evaluasi ini tidak perlu dilakukan setiap kali ada kerja kelompok, tetapi bisa dilakukan selang beberapa waktu setelah beberapa kali siswa terlibat dalam kegiatan pembelajaran kooperatif.

Apabila lima unsur dalam penerapan pembelajaran kooperatif tersebut diterapkan dengan baik maka hasil yang maksimal akan dicapai dalam proses pembelajaran ini

\section{Langkah-langkah Pembelajaran Kooperatif}

Terdapat enam langkah utama atau tahapan di dalam pelajaran yang menggunakan pembelajaran kooperatif. ${ }^{11}$ Pembelajaran dalam kooperatif dimulai dengan guru menyampaikan tujuan pelajaran dan memotivasi siswa untuk belajar. Fase ini diikuti oleh penyajian informasi, sering kali dengan bahan bacaan daripada secara verbal. Selanjutnya siswa dikelompokkan ke dalam tim-tim belajar. Tahap ini diikuti bimbingan guru pada saat siswa bekerja bersama untuk menyelesaikan tugas bersama mereka. Fase terakhir pembelajaran kooperatif meliputi presentasi hasil akhir kerja kelompok, atau evaluasi tentang apa yang telah mereka pelajari dan memberi penghargaan terhadap usaha-usaha kelompok maupun individu.

${ }^{11}$ Rusman, Model-model Pembelajaran: Mengembangkan .., hal. 211

Vol.I. No.⒉ April 2019

Jurnal Auladuna | 83 


\section{Kelebihan dan Kekurangan Pembelajaran Kooperatif}

Kelebihan pembelajaran kooperatif sebagai suatu strategi pembelajaran diantaranya:

a. Melalui pembelajaran kooperatif siswa tidak terlalu menggantungkan pada guru, akan tetapi dapat menambah kepercayaan kemampuan berpikir sendiri, menemukan informasi dari berbagai sumber, dan belajar dari siswa lain.

b. Melalui pembelajaran kooperatif dapat mengembangkan kemampuan mengungkapkan ide atau gagasan dengan kata-kata secara verbal dan membandingkannya dengan ide-ide orang lain.

c. Pembelajaran kooperatif dapat membantu anak untuk respek pada orang lain dan menyadari akan segala keterbatasannya serta menerima segala perbedaan.

d. Pembelajaran kooperatif dapat membantu memberdayakan setiap siswa untuk lebih bertanggung jawab dalam belajar.

e. Pembelajaran kooperatif merupakan suatu strategi yang cukup ampuh untuk meningkatkan prestasi akademik sekaligus kemampuan sosial, termasuk mengembangkan rasa harga diri, hubungan interpersonal yang positif dengan yang lain, dan sikap positif terhadap sekolah.

f. Melalui pembelajaran kooperatif dapat mengembangkan kemampuan siswa untuk menguji ide dan pemahamannya sendiri, serta menerima umpan balik.

g. Pembelajaran kooperatif dapat meningkatkan kemampuan siswa menggunakan informasi dan kemampuan belajar abstrak menjadi nyata.

h. Interaksi selama kooperatif berlangsung dapat meningkatkan motivasi dan memberikan rangsangan untuk berpikir. Hal ini berguna untuk proses pendidikan jangka panjang. ${ }^{12}$

Dari uraian di atas dapat ditarik kesimpulan bahwa pembelajaran kooperatif dapat menyebabkan unsur-unsur psikologi siswa menjadi terangsang dan menjadi lebih aktif. Hal ini disebabkan adanya rasa kebersamaan dalam kelompok, sehingga mereka dengan mudah dapat berkomunikasi dengan bahasa yang lebih sederhana. Pada saat berdiskusi fungsi ingatan dari siswa menjadi lebih aktif, lebih bersemangat, dan berani mengemukakan pendapat. Pembelajaran kooperatif juga dapat meningkatkan kerja keras siswa, lebih giat, dan lebih

12 Wina Sanjaya, Strategi Pembelajaran Berorientasi Standar Proses Pendidikan, (Jakarta: Kencana, 2007), hal. 247-249 84 | Jurnal Auladuna 
termotivasi. Disamping kelebihan, pembelajaran kooperatif juga memiliki kekurangan, diantaranya:

a. Guru harus mempersiapkan pembelajaran secara matang, disamping itu proses pembelajaran kooperatif memerlukan lebih banyak tenaga, pemikiran, dan waktu.

b. Membutuhkan dukungan fasilitas, alat, dan biaya yang cukup memadai.

c. Selama kegiatan diskusi kelompok berlangsung, ada kecenderungan topik permasalahan yang dibahas meluas. Dengan demikian, banyak yang tidak sesuai dengan waktu yang ditentukan.

d. Saat diskusi kelas, terkadang didominasi oleh seseorang. Hal ini mengakibatkan siswa yang lain menjadi pasif. ${ }^{13}$

Dari uraian di atas dapat disimpulkan, untuk menyelesaikan suatu materi pelajaran dengan pembelajaran kooperatif akan memakan waktu yang relatif lebih lama dibandingkan dengan pembelajaran konvensional, bahkan dapat menyebabkan materi tidak dapat disesuaikan dengan kurikulum yang ada apabila guru belum berpengalaman. Dari segi keterampilan mengajar, guru membutuhkan persiapan yang matang dan pengalaman yang lama untuk dapat menerapkan pembelajaran kooperatif dengan baik.

\section{B. Hakekat Pembelajaran Kooperatif Tipe Talking Stick}

\section{Pengertian Model Talking Stick}

Pembelajaran merupakan suatu kombinasi yang tersusun meliputi unsur-unsur manusiawi, material, fasilitas, perlengkapan, dan prosedur yang saling mempengaruhi tujuan pembelajaran. Tujuan pembelajaran yang dimaksud adalah perubahan tingkah laku yang positif dan lebih baik. Dengan kata lain bahwa proses pembelajaran adalah proses yang berkesinambungan antara pembelajar dengan segala sesuatu yang menunjang perubahan tingkah laku. Dalam proses berkesinambungan itulah perlu adanya model pembelajaran yang dianggap tepat.

Talking stick (tongkat berbicara) adalah model pembelajaran kelompok dengan bantuan tongkat. Kelompok yang memegang tongkat terlebih dahulu wajib menjawab pertanyaan dari guru setelah mereka mempelajari materi pokoknya. Kegiatan ini diulang terus-menerus sampai semua kelompok mendapat giliran untuk menjawab pertanyaan dari guru. Talking Stick

\footnotetext{
${ }^{13}$ Muhammad Thobroni dan Arif Mustofa, Belajar dan Pembelajaran: Pengembangan Wacana dan Praktik Pembelajaran dalam Pembangunan Nasional, (Jogjakarta: Ar-Ruzz Media, 2013), hal. 292-293

Vol.DI. No.DZ. April 2019 
merupakan salah satu tipe pembelajaran kooperatif yang sederhana. Dalam penerapan model talking stick, guru membagi kelas menjadi kelompok-kelompok dengan anggota lima atau enam siswa yang heterogen. ${ }^{14}$ Kelompok dibentuk dengan mempertimbangkan keakraban, kecerdasan, persahabatan, atau minat yang berbeda.

\section{Langkah-langkah Pembelajaran Kooperatif Tipe Talking Stick}

Adapun langkah-langkah penerapan pembelajaran kooperatif tipe talking stick adalah: ${ }^{15}$

a. Pembentukan kelompok, guru membagi kelas menjadi kelompok-kelompok dengan anggota enam siswa yang heterogen. Kelompok dibentuk dengan mempertimbangkan keakraban, kecerdasan, persahabatan, atau minat yang berbeda.

b. Penyiapan tongkat, guru menyiapkan sebuah tongkat yang panjangnya $\pm 20 \mathrm{~cm}$.

c. Penyampaian materi, guru menyampaikan materi memahami surat al-Qadr, kemudian memberikan kesempatan para kelompok untuk membaca dan mempelajari materi memahami surat Al-Qadr. Setelah siswa selesai membaca materi memahami surat Al-Qadr dan mempelajari isinya, guru mempersilahkan siswa untuk menutup isi bacaan.

d. Pemberian tongkat, guru mengambil tongkat dan memberikannya kepada salah satu siswa. Pemberian tongkat dilakukan dengan cara bernyanyi. Seluruh siswa menyanyikan lagu "aina dimana" sambil tongkat terus bergulir dari satu siswa ke siswa berikutnya sampai peneliti mengatakan "stop".

e. Menjawab pertanyaan, guru memberi pertanyaan dan siswa yang memegang tongkat tersebut harus menjawabnya. Demikian seterusnya sampai sebagian besar siswa mendapat bagian untuk menjawab setiap pertanyaan dari guru.

f. Guru memberi kesimpulan.

g. Guru melakukan evaluasi atau penilaian.

h. Guru menutup pembelajaran.

\section{Kelebihan dan Kekurangan Model Talking Stick}

Model talking stick memiliki kelebihan sebagai berikut:

\footnotetext{
${ }_{14}$ Miftahul Huda, Model-model Pengajaran dan Pembelajaran: Isu-isu Metodis dan Paradigmatis, (Yogyakarta: Pustaka Pelajar, 2014), hal. 224

${ }^{15}$ Miftahul Huda, Model-model Pengajaran, hal.225

86 | Jurnal Auladuna

Vol.DI. No.Z2. April 2019
} 
a. Cocok digunakan untuk semua kelas dan semua tingkatan umur

b. Mampu menguji kesiapan siswa

c. Melatih keterampilan siswa dalam membaca dan memahami materi pelajaran dengan cepat.

d. Mengajak siswa untuk terus siap dalam situasi apa pun.

Model talking stick selain memiliki kelebihan juga memiliki kekurangan sebagai berikut:

a. Membuat siswa senam jantung

b. Siswa yang tidak siap tidak bisa menjawab

c. Membuat peserta didik tegang

d. Ketakutan akan pertanyaan yang akan diberikan oleh guru. ${ }^{16}$

\section{Hakekat Pembelajaran Al-Qur'an Hadits}

1. Pengertian Al-Qur'an Hadits

Pendidikan agama Islam di Madrasah Ibtidaiyah terdiri atas empat mata pelajaran, yaitu: Al-Qur'an Hadits, Aqidah Akhlak, Fiqih, dan Sejarah Kebudayaan Islam. Masing-masing mata pelajaran tersebut pada dasarnya saling terkait, isi mengisi, dan melengkapi.

Daradjat mengemukakan bahwa:

Al-Qur'an Hadits merupakan perencanaan dan pelaksanaan program pengajaran membaca dan mengartikan atau menafsirkan ayat-ayat al-Qur'an dan Hadits tertentu, yang sesuai dengan kepentingan siswa menurut tingkat-tingkat madrasah yang bersangkutan, sehingga dapat dijadikan modal kemampuan untuk mempelajari, meresapi dan menghayati pokok-pokok Al-Qur'an dan Al-Hadits dan menarik hikmah yang terkandung di dalam secara keseluruhan. Al-Qur'an dan Al-Hadits merupakan sumber utama ajaran Islam, dalam arti Al-Qur'an Hadits merupakan sumber Aqidah Akhlak, Syarie ah atau Fiqih (ibadah, muamalah), sehingga kajiannya berada di setiap unsur tersebut.

2. Karakteristik Pembelajaran Al-Qur'an Hadits

Mata pelajaran Al-Qur'an Hadits di Madrasah Ibtidaiyah adalah salah satu mata pelajaran pendidikan agama Islam yang menekankan pada kemampuan membaca dan menulis al-Qur'an dan hadits dengan benar, serta hafalan terhadap surat-surat pendek dalam al-Qur'an, pengenalan arti atau makna secara sederhana dari surat-surat pendek tersebut dan hadits-hadits tentang akhlak terpuji untuk diamalkan dalam kehidupan sehari-hari melalui keteladanan dan pembiasaan. Hal ini sejalan dengan misi pendidikan dasar adalah untuk:

${ }^{16}$ Miftahul Huda, Model-model Pengajaran,.hal. 225

Vol.Jl. №.I2. April 2019

Jurnal Auladuna | 87 
a. Pengembangan potensi dan kapasitas belajar peserta didik, yang menyangkut rasa ingin tahu, percaya diri, keterampilan berkomunikasi, dan kesadaran diri.

b. Pengembangan kemampuan baca, tulis, hitung dan bernalar, keterampilan hidup, dasar-dasar keimanan dan ketaqwaan terhadap Tuhan Yang Maha Esa.

c. Fondasi bagi pendidikan berikutnya. ${ }^{17}$

Secara substansial mata pelajaran Al-Qur'an Hadits memiliki kontribusi dalam memberikan motivasi kepada peserta didik untuk mencintai kitab sucinya, mempelajari dan mempraktikkan ajaran dan nilai-nilai yang terkandung dalam Al-Qur'an Hadits sebagai sumber utama ajaran Islam dan sekaligus menjadi pegangan dan pedoman hidup dalam kehidupan sehari-hari.

3. Ruang Lingkup Pembelajaran Al-Qur'an Hadits

Ruang lingkup mata pelajaran Al-Qur'an Hadits di Madrasah Ibtidaiyah meliputi: ${ }^{18}$

a. Pengetahuan dasar membaca dan menulis Al-Qur'an yang benar sesuai dengan kaidah ilmu tajwid.

b. Hafalan surat-surat pendek dalam Al-Qur'an dan pemahaman sederhana tentang arti dan makna kandungannya serta pengamalannya melalui keteladanan dan pembiasaan dalam kehidupan sehari-hari.

c. Pemahaman dan pengamalan melalui keteladanan dan pembiasaan mengenai hadits yang berkaitan dengan kebersihan, niat, menghormati orang tua, persaudaraan, silaturahmi, taqwa, menyayangi anak yatim, shalat berjamaah, ciri-ciri orang munafik, dan amal salih.

Materi Al-Qur'an Hadits semula terdiri dari dua bidang mata pelajaran yaitu bidang AlQur'an dan bidang Hadits, kemudian diintegrasikan menjadi satu bidang mata pelajaran AlQur'an Hadits. Sekalipun demikian di dalamnya tidak bisa dilepaskan dari dua bidang tersebut. Jika dijumlah materi Al-Qur'an sebanyak 21 surat yakni dari surat al-Fatihah sampai dengan adDhuha. Secara rinci dapat disebutkan satu persatu yaitu surat al-Fatihah, an-Nas, al-Falaq, alIkhlash, al-Lahab, an-Nashr, Al-Kafirun, Al-Kautsar, Al-Maeeun, Al-Quraisy, Al-Fil, Al-

17 Rini Azzahra, "Karakteristike Pengelolaan Pembelajaran Al-Qur'an Hadits di Madrasah Ibtidaiyab", dalam http://reyneeazzahra.wordpress.com/2013/02/05/karakteristik-pengelolaan-pembelajaran-al-qur"an-hadits-dimadrasah-ibtidaiyah, diakses 15 Februari 2018 $18 \mathrm{ibid}$

88 | Jurnal Auladuna

Vol.DI. No.Q2. April 2019 
Humazah, Al-Ashr, At-Takatsur, Al-Qariah, Al-Adiyat, Al-Zalzalah, Al-Bayyinah, Al-Qadr, AlAlaq, At-Tin, Al-Insyirah, dan Ad-Dhuha.

Sedangkan materi Hadits terdiri dari minimal 10 hadits secara tematik yaitu tentang kebersihan, niat, menghormati orang tua, persaudaraan, silaturahim, taqwa, menyayangi anak yatim, shalat berjamaah, ciri-ciri orang munafik, dan amal salih. Sebagai materi pendukung adalah sebagai berikut:

a. Keterampilan baca tulis huruf hijaiyah dengan benar (makhraj)

b.Kaidah ilmu tajwid, meliputi:

1) Waqaf (berhenti) dan washal (berlanjut)

2) Al-Qamariyah dan Al-Syamsiyah

3) Mad thabie i, mad wajib muttashil dan mad jaiz munfashil

4) Bacaan nun sukun dan tanwin (izhar, ikhfa ${ }^{e e}$ idgham bighunnah, idgham bilaghunnah, dan iqlab).

Dengan demikian materi Al-Qur'an Hadits di Madrasah Ibtidaiyah terdiri dari dua materi, yakni: materi pokok dan materi pendukung. Materi pokok adalah materi Al-Qur'an dan Hadits sedang materi pendukung adalah materi pengantar dari segi pengenalan baca tulis huruf hijaiyah serta kaidah ilmu tajwid.

\section{KESIMPULAN}

Pembelajaran kooperatif tipe talking stick adalah tipe yang cukup menyenangkan yang digunakan untuk mengulang materi yang telah disampaikan maupun materi baru yang akan diajarkan pun dapat menggunakan model ini, dengan catatan bahwa sebelum materi diajarkan guru harus memberitahu siswa agar belajar supaya ketika penerapan model ini mereka mempunyai bekal pengetahuan. Alasan lain dipilihnya pembelajaran kooperatif tipe talking stick adalah dapat memudahkan siswa memahami materi yang sulit dengan waktu yang relatif singkat pada pembelajaran Al-Qur'an Hadits. Madrasah ini memiliki jumlah siswa yang relatif banyak, sehingga secara otomatis akan menghasilkan output yang banyak pula. Siswa yang telah mahir dalam melafalkan ayat-ayat Al-Qur'an sesuai dengan makhraj dan tajwidnya, sudah dibiasakan 
sejak dini untuk menjadi imam sholat ketika sholat dhuha dan sholat dhuhur di Madrasah sehingga siswa akan selalu ingat dan terbiasa dalam melafalkan ayat-ayat pendek.

\section{DAFTAR PUSTAKA}

Agus Suprijono, 2009 Cooperative Learning: Teori dan Aplikasi PAIKEM, (Yogyakarta: Pustaka Pelajar)

Anita Lie, 2007. Cooperative Learning: Mempraktikean Cooperative Learning di Ruang-ruang Kelas, (Jakarta: Gramedia).

Annisatul Mufarrokah, 2009. Strategi Belajar Mengajar, (Yogyakarta: Teras)

Isjoni, 2011. Cooperative Learning: Mengembangkan Kemampuan Belajar Berkelompok, (Bandung: Alfabeta).

Miftahul Huda, 2014. Model-model Pengajaran dan Pembelajaran: Isu-isu Metodis dan Paradigmatis, (Yogyakarta: Pustaka Pelajar).

Muhammad Thobroni dan Arif Mustofa, 2013. Belajar dan Pembelajaran: Pengembangan Wacana dan Praktik Pembelajaran dalam Pembangunan Nasional, (Jogjakarta: Ar-Ruzz Media).

Nur Asma, 2006. Model Pembelajaran Kooperatif, (Jakarta: Departemen Pendidikan Nasional).

Rusman, 2012. Model-model Pembelajaran: Mengembangkan Profesionalisme Guru, (Jakarta: PT. Raja Grafindo Persada).

Undang-Undang RI No. 20 Tabun 2003 tentang Sistem Pendidikan Nasional, (Jakarta: Sinar Grafida, 2009)

Wina Sanjaya, 2007. Strategi Pembelajaran Berorientasi Standar Proses Pendidikan, (Jakarta: Kencana). Zakiah Daradjat, dkk., 2008. Metodik Khusus Pengajaran Agama Islam, (Jakarta: Bumi Aksara).

Lily Azkiya, Plajaran Hadits, dalam http://www.slideshare.net/HazanaItriya/alquran-hadits-misd, diakses 15 Februari 2018.

Rini Azzahra, Karakteristike Pengelolaan Pembelajaran Al-Qur'an Hadits di Madrasah.Ibtidaiyah ,dalam.http://reyneeazzahra.wordpress.com/2013/02/05/ka rakteristik-pengelolaanpembelajaran-al-qur an-hadits-di-madrasah-ibtidaiyah,diakses 15 Februari 2018 